\title{
Disputed paper still causing problems
}

\section{- NIH re-opens Baltimore case - Dingell inquiry alarms researchers}

\section{Washington}

IN a surprise move, the National Institutes of Health (NIH) last week decided to reopen its inquiry about a disputed paper published in Cell in 1986. The decision comes on the eve of two congressional hearings - one scheduled for today and the other for next Tuesday - on the handling of misconduct investigations in science, with a particular emphasis on the Cell paper.

Intense interest mixed with apprehension has attended the plans of the House of Representatives energy and commerce subcommittee on oversight and investigation to continue its investigation into the Cell paper. The Secret Service is expected to testify at today's hearings about forensic tests performed on the laboratory notes of Thereza Imanishi-Kari, the paper's principal author, and rumours have been rampant that this testimony will reveal some unacceptable tampering.

But Nobel laureate David Baltimore is certain to be the star witness at the hearings. Baltimore, director of the Whitehead Institute at Cambridge, has acted as spokesman for questions about the disputed paper (Cell 45, 247: 1986) of which he was a co-author with David Weaver, Moema Reis, Christopher Albanese and Imanishi-Kari, all then of Massachusetts Institute of Technology (MIT), and Frank Costantini of Columbia University. Imanishi-Kari is now at Tufts University.

Colleagues of Baltimore are rallying to his support, claiming that a scientific argument is turning into a witch hunt.

Phillip Sharp of MIT has sent out a "Dear Colleague" letter asking for help in countering the activities of the investigations subcommittee. Sharp says in his letter that the committee "has decided to hassle David and other authors and this has serious implications for all of us". He added in an interview that draconian investigations of laboratory research "will destroy science in this country".

An NIH review panel last year cleared Baltimore and his colleagues of allegations of misconduct (see Nature 336, 505; 1988) and recommended that the matter be settled with a note of correction to Cell. $\mathrm{NIH}$ director James Wyngaarden says the decision to reopen the inquiry came after a series of specific criticisms of the paper were made in letters from Margot O'Toole, the postdoctoral student in the laboratory of Imanishi-Kari who began the controversy over the paper's validity in 1986 .
O'Toole's letters point out that not all the data on which the paper was based could be found in laboratory notebooks supplied to NIH's review panel by the paper's authors. The three-member review panel, made up of Joseph Davie of Searle Pharmaceuticals, Hugh McDevitt of Stanford University and Ursula Storb of the University of Chicago, had checked the data on which the paper was based, according to Wyngaarden, but had not carried out a "complete audit point by point". Wyngaarden says he was "not satisfied with the answers" he had received to preliminary inquiries into the newly discovered discrepancy and had decided to re-open the inquiry with "a more careful data audit".

Behind Wyngaarden's careful words lie the worry that the congressional inquiry may seize on errors in the paper as evidence of serious misconduct and attack the ability of scientists to police their colleagues. Congressional subcommittee chairman John Dingell has already pointed out that he regards NIH's performance in the Baltimore case as a "crucial test of their ability to deal with cases of questioned science" (see Nature 337, 490; 1989).

But few scientists have been prepared for how far he would go in his investigation. Files and letters have been requisitioned by the committee from authors of the Cell paper in a manner more reminiscent of an attack on an organized crime syndicate than a check on two graphs and a table in a three-year-old scientific paper.

That the quarrel over the paper has become so important is largely due to the activity of Walter Stewart and Ned Feder, two NIH scientists well known for their analyses of scientific misconduct. O'Toole raised questions about the paper's validity soon after it was published. But two informal inquiries, neither of which examined the raw data on which the paper was based, failed to find evidence of serious error. The matter might have ended there if Stewart and Feder had not become involved and circulated a controversial analysis of the Cell paper, partly based on 17 pages of a notebook allegedly from Imanishi-Kari's laboratory.

The analysis helped to fire two congressional hearings on scientific misconduct in April 1988. Stewart then became a temporary member of the Dingell subcommittee's staff, working on the Baltimore case. Baltimore did not have an opportunity to defend himself at

\section{HUGO to go international \\ Washington}

THE one-year-old Human Genome Organization (HUGO), meeting last week at Cold Spring Harbor Laboratory in New York, is to open three regional offices: at Osaka University in Japan under Kenichi Matsubara, at the Imperial Cancer Research Fund in London under Sir Walter Bodmer, and at the Howard Hughes Medical Institute on the campus of the US National Institutes of Health.

HUGO President Victor McKusick says that the organization will add a mouse genome committee to those on physical mapping and databases, and will structure the organization much like a national academy of sciences, where potential members must be nominated and voted upon. HUGO now has 220 members from 23 countries. Elections will be held later this year to constitute an 18-member governing council.

Carol Ezzell

\section{VENUS PROBE \\ May 'window' still the target}

\section{Washington}

THE Magellan Venus radar mapping spacecraft was 31 seconds away from launch last Friday, 28 April, aboard the space shuttle Atlantis when a pump in the shuttle's main engine cooling system failed, forcing postponement. The launch has been rescheduled for today, at $1.48 \mathrm{pm}$ Eastern Daylight Time. It is critical that Magellan be launched before 28 May. After that the alignment of the planets will no longer permit the spacecraft to reach Venus, and the mission - already much postponed - will have to be delayed for at least 18 months. Joseph Palca

either hearing. The NIH review panel was set up in June.

By the time that panel had presented its draft report in November, Baltimore had already published a letter in Cell $\mathbf{( 5 5}, 541$; 1988) that corrected three "misstatements" in his original paper (Nature 336, $295 ; 1988)$. But the NIH panel was not satisfied. While it cleared Baltimore and colleagues of misconduct or fraud, it agreed with many of O'Toole's original criticisms of the paper and asked for a further letter of correction.

That letter will be soon be published in Cell, according to a Whitehead spokesman. But with the NIH inquiry reopened and the congressional hearings imminent, it is now anyone's guess as to how the affair will end. O'Toole, who says she left her career in science as a result of the reaction to her complaints, still says the full truth has not come out.

Alun Anderson \& Joseph Palca 